\title{
PENERAPAN MODEL PEMBELAJARAN KOOPERATIF TIPE STAD UNTUK MENINGKATKAN HASIL BELAJAR IPA
}

\author{
I Putu Ari Sudana ${ }^{1 *}$, I Gede Astra Wesnawa ${ }^{2}$ \\ 1 Universitas Pendidikan Ganesha \\ 2 Universitas Pendidikan Ganesha
}

\begin{abstract}
Abstrak
Penelitian ini bertujuan untuk mengetahui peningkatan hasil belajar IPA siswa kelas IV A di SD No. 3 Dalung, Kecamatan Kuta Utara, Badung. Penelitian ini adalah penelitian tindakan kelas dengan subjek penelitian adalah siswa kelas IV A semester ganjil SD No. 3 Dalung Tahun Pelajaran 2016/2017 yang berjumlah 28 orang dan objek penelitiannya adalah hasil belajar IPA. Data dikumpulkan dengan menggunakan teknik observasi dan metode tes. Selanjutnya diolah menggunakan tehnik analisis deskriptif kuantitatif. Hasil penelitian ini menujukan bahwa persentase hasil belajar IPA siswa pada siklus I sebesar $62 \%$ dengan katagori "Rendah" pada siklus II sebesar $88 \%$ dengan katagori "Tinggi”. Peningkatan hasil belajar IPA dari siklus I ke Siklus II sebesar $26 \%$. Hasil penelitian menunjukkan bahwa penerapan model pembelajaran Tipe STAD dapat meningatkan hasil belajar IPA siswa kelas IV A semester ganjil Tahun Pelajaran 2016/2017 di SD No. 3 Dalung.
\end{abstract}

\author{
Keywords: \\ IPA, hasil belajar, \\ STAD.siswa dalam mata \\ pelajaran PKn.
}

\section{Pendahuluan}

Pendidikan adalah usaha sadar untuk menyiapkan peserta didik melalui kegiatan bimbingan, pengajaran, dan/atau latihan bagi perannannya di masa yang akan datang” (UU R.I. No. 2 Tahun 1989 I, Pasal 1).

Sekolah sebagai suatu lembaga pendidikan formal, secara sistematis merencanakan bermacammacam lingkungan, yakni lingkungan pendidikan yang menyediakan berbagai kesempatan bagi peserta didik untuk melakukan berbagai kegiatan belajar. Dengan berbagai kesempatan belajar, pertumbuhan dan perkembangan peserta didik diarahkan dan didorong ke arah pencapaian tujuan yang dicita-citakan. Lingkungan tersebut disusun dan ditata dalam suatu kurikulum, yang pada gilirannya dilaksanakan dalam bentuk proses pembelajaran (Hamalik 2014)

Hal tersebut menuntut guru untuk lebih kreatif dan inovatif dalam menyusun dan merencanakan pembelajaran yang sesuai dengan situasi dan kondisi siswa. Untuk mewujudkan pendidikan yang berkualitas seperti dijelaskan di atas dalam bentuk realitas bukanlah suatu pekerjaan yang mudah. Perubahan paradigma pembelajaran yang awalnya proses pembelajaran berpusat pada guru (teacher centered) berubah menjadi kegiatan pembelajaran yang berpusat pada siswa (student centered). Guru diharapkan dapat membantu siswa dalam memecahkan masalah tersebut agar tujuan pendidikan nasional dapat tercapai sesuai dengan yang diharapkan. Secara umum, sekolah dasar diselenggarakan dengan tujuan untuk mengembangkan sikap serta memberikan pengetahuan dan keterampilan dasar yang diperlukan untuk hidup di masyarakat. Tujuan tersebut dapat tercapai melalui pendidikan dan pengajaran dari disiplin ilmu pengetahuan Alam (IPA).

Pembelajaran IPA yang berkembang saat ini khususnya di Sekolah Dasar menuntut siswa agar menemukan masalah serta memecahkannya. Margunayasa (2013) Dalam pembelajaran IPA guru dituntut untuk mengajak siswa memanfaatkan alam sebagai sumber belajar. IPA memberikan banyak manfaat bagi siswa, diantaranya siswa dapat mengenal lingkungan sekitar, mendapatkan pengalaman langsung dengan melakukan berbagai percobaan yang terkait dengan lingkungan hidup. IPA adalah ilmu pengetahuan yang mempelajari objek-objek alam semesta beserta isinya. Dalam pembelajaran IPA siswa harus diberikan kesempatan untuk mengalami dan menemukan sendiri tentang makna dari materi yang diajarkan dengan berpikir kritis sehingga mudah dipahami siswa dalam mata pelajaran IPA. Oleh karena itu, pembelajaran IPA di Sekolah Dasar menekankan pada pemberian pengalaman belajar secara langsung. Pengembangan

* Corresponding author.

E-mail Addresses: ari_sudana@yahoo.com (I Putu Ari Sudana) gede_astrawesnawa@yahoo.co.id (I Gede Astra Wesnawa)) 
keterampilan proses sangat menunjang dalam menggali pengetahuan siswa dari alam bebas. Dari keterampilan proses ini dapat dikembangkan sikap ilmiah.

Kondisi saat ini, khususnya dalam proses pembelajaran IPA terlihat guru lebih dominan menggunakan tehnik lama, kurangnya variasi guru dalam mengajar dan minimnya penggunaan media pembelajaran. Guru kurang menggunakan model pembelajaran yang dapat membuat siswa aktif, sehingga pembelajaran terlihat pasif, siswa kurang termotivasi untuk belajar, pengembangan sikap siswa dalam proses pembelajaran juga masih kurang, siswa kurang aktif dalam bertanya dan mengeluarkan pendapat. Demikian pula dengan sikap bertanggung jawab, sikap ingin tahu dan bekerjasama siswa dalam menyelesaikan tugas masih kurang yang diakibatkan oleh kurangnya penggunaan metode dan media pembelajaran yang bervariasi. Hal ini terlihat ketika siswa kelas IV A belajar materi mahluk hidup dan lingkungan pada tanggal 10 Oktober 2017 tanpa menggunakan model pembelajaran. Banyak siswa yang kurang mengerti bahkan keliru tentang rantai makanan.

Untuk membuktikan permasalahan-permasalahan yang sering terjadi di sekolah dasar, maka dilakukan observasi pada hari senin, 10 oktober 2016 selama kegiatan pembelajaran IPA berlangsung guru tampak mendominasi kelas dengan memberi ceramah. Kegiatan observasi dilakukan di kelas IV tepatnya di SD No. 3 Dalung, Kecamatan Kuta Utara, Kabupaten Badung. Dari hasil observasi dapat dilihat bahwa guru masih menggunakan teknik pembelajaran lama yang lebih banyak melakukan ceramah dan tanya jawab selama kegiatan pembelajaran berlangsung. Kegiatan pembelajaran hanya terpusat pada guru (teacher center) sehingga siswa cenderung kurang aktif selama kegiatan pembelajaran IPA berlangsung. Selain itu sumber belajar yang digunakan kurang bervariasi dan hanya menggunakan buku penunjang sebagai sumber belajar utama siswa. Berdasarkan hasil wawancara dengan wali kelas IV dan hasil observasi diperoleh data yang menunjukkan bahwa nilai rata-rata siswa yaitu 59,3 dari KKM yang telah ditetapkan 75. Dari 28 siswa secara keseluruhan, 12 siswa (42\%) sudah memenuhi KKM dan 16 (58 \%) siswa belum memenuhi KKM yang telah ditetapkan. Hal ini disebabkan karena guru masih menggunakan teknik belajar lama yaitu tanya jawab.

Dari uraian di atas, maka perlu adanya perubahan dalam pembelajaran IPA. Agar pembelajaran IPA dapat efektif dan kreatif maka guru harus bisa menentukan suatu model, karena model adalah suatu prosedur yang dipakai untuk mencapai tujuan tertentu. Semakin tepat model pembelajaran yang digunakan oleh guru dalam mengajar, diharapkan semakin efektif pula pencapaian tujuan pembelajaran. Salah satu model yang cocok diterapkan pada pembelajaran IPA adalah model pembelajaran kooperatif tipe Student Team Achievement Division (STAD). Model pembelajaran kooperatif tipe STAD merupakan salah satu metode kooperatif yang paling sederhana, dan merupakan model yang paling baik untuk permulaan bagi para guru yang baru menggunakan pendekatan

Menurut Rusman (2013) Model Kooperatif tipe STAD dikembangkan oleh Robert Slavin dan kolega-koleganya di Universitas John Hopkin. Menurut Slavin (2013) STAD merupakan salah satu model pembelajaran kooperatif yang paling sederhana, dan merupakan salah satu model yang banyak digunakan dalam pembelajaran kooperatif. menjelaskan bahwa pembelajaran kooperatif dengan model STAD, siswa ditempatkan dalam kelompok belajar kemampuan akademik yang berbeda, sehingga dalam setiap kelompok terdapat siswa yang berprestasi tinggi, sedang, dan rendah atau variasi jenis kelamin, kelompok ras dan etnis, atau kelompok sosial lainnya.

Ruang lingkup bahan kajian IPA di SD secara umum meliputi dua aspek yaitu kerja ilmiah dan pemahaman konsep. Lingkup kerja ilmiah meliputi kegiatan penyelidikan, berkomunikasi ilmiah, pengembangan kreativitas, pemecahan masalah, sikap, dan nilai ilmiah. Lingkup pemahaman konsep dalam Kurikulum KTSP relatif sama jika dibandingkan dengan Kurikulum Berbasis Kompetensi (KBK) yang sebelumnya digunakan. Secara terperinci lingkup materi yang terdapat dalam Kurikulum KTSP adalah: (1) makhluk hidup dan proses kehidupannya, yaitu manusia, hewan, tumbuhan dan interaksinya dengan lingkungan, serta kesehatan. (2) benda atau materi, sifat-sifat dan kegunaannya meliputi: cair, padat dan gas. (3) energi dan perubahaannya meliputi: gaya, bunyi, panas, magnet, listrik, cahaya, dan pesawat sederhana. (4) bumi dan alam semesta meliputi: tanah, bumi, tata surya, dan benda-benda langit lainnya. Dengan demikian, dalam pelaksanaan pembelajaran IPA kedua aspek tersebut saling berhubungan. Aspek kerja ilmiah diperlukan untuk memperoleh pemahaman atau penemuan konsep IPA.

Kelima prinsip tersebut memberikan kontribusi terhadap keberhasilan Pembelajaran IPA di sekolah dasar seharusnya dilakukan berdasarkan prinsip-prinsip di atas. Di samping itu, pendidikan IPA di sekolah dasar hendaknya membuka kesempatan untuk memupuk rasa ingin tahu anak secara alamiah. Hal tersebut disebabkan karena pada dasarnya siswa sekolah dasar kesehariannya selalu berhadapan dengan alam yang merupakan objek dari pembelajaran IPA. Jika hal tersebut dapat dilakukan dengan baik oleh para guru, maka hakikat pembelajaran IPA di sekolah dasar yang meliputi proses dan produk akan berhasil dicapai. Berdasarkan penjelasan-penjelasan di atas, dapat disimpulkan bahwa keberhasilan pembelajaran IPA ditentukan oleh kreativitas guru dalam mengemas pembelajaran tersebut untuk 
menciptakan suasana pembelajaran yang menarik. Di samping itu, pembelajaran IPA harus dapat memfasilitasi minat dan bakat siswa, berorientasi pada penemuan dan pengalaman, dapat memberikan keadilan kepada siswa untuk memperoleh kesempatan belajar yang sama, serta melibatkan siswa secara aktif untuk memperoleh pengetahuan yang diperlukan (Trianto, 2015)

Hasil belajar, yaitu perubahan-perubahan yang terjadi pada diri siswa, baik yang menyangkut aspek kognitif, afektif, dan psikomotor sebagai hasil dari kegiatan belajar. Pengertian tentang hasil belajar sebagaimana diuraikan di atas dipertegas oleh Nawawi dalam K. Brahim (2007) yang menyatakan bahwa hasil belajar dapat diartikan sebagai tingkat keberhasilan siswa dalam mempelajari materi pelajaran di sekolah yang dinyatakan dalam skor yang diperoleh dari hasil tes mengenal sejumlah materi pelajaran tertentu. Secara sederhana, yang dimaksud dengan hasil belajar siswa adalah kemampuan yang diperoleh anak setelah melalui kegiatan belajar. Karena belajar itu sendiri merupakan suatu proses dari seseorang yang berusaha untuk memperoleh suatu bentuk perubahan perilaku yang relatif menetap. Dalam kegiatan pembelajaran atau kegiatan instruksional, biasanya guru menetapkan tujuan belajar. Anak yang berhasil dalam belajar adalah yang berhasil mencapai tujuan-tujuan pembelajaran atau tujuan instruksional.

Menurut Purwanto (2000) "hasil belajar dari tiap-tiap topik bahan pelajaran tidak selalu sama". Bloom (dalam Sutrisno, 2008) menyatakan bahwa hasil belajar tercemin dalam tiga ranah (domain), yaitu ranah kognitif, afektif dan psikomotor. Hasil belajar akan tercermin dalam ketiga ranah itu secara simulta Nurkancana dan Sunartana (1992) menyatakan "Hasil belajar adalah suatu tindakan atau suatu proses untuk menentukan nilai keberhasilan belajar seseorang setelah ia mengalami proses belajar selama satu periode tertentu".

Berdasarkan teori yang disebutkan oleh para ahli diatas, dapat disintesiskan hasil belajar merupakan proses perubahan tingkah laku individu seseorang melalui interaksi dengan lingkungannya. Perubahan tingkah laku ini meliputi aspek afektif (sikap), kognitif (pengetahuan) dan psikomotorik (ketrampilan).

\section{Metode}

Penelitian ini adalah penelitian tindakan kelas (Classroom action research). Penelitian ini akan dilaksanakan dalam beberapa siklus. Masing-masing siklus terdiri dari empat tahapan, yaitu: perencanaan tindakan, pelakasanaan tindakan, observasi dan evaluasi dan refleksi. Dari penelitian ini diharapkan dapat memberikan hasil yang optimal. Tindakan yang dilakukan adalah melalui pendekatan keterampilan proses. Untuk itu dilakukan penelitian dari hari senin, 10 Oktober 2016 sampai 1 November 2017 di SD No. 3 Dalung.

Adapun rancangan dari penelitian tindakan kelas ini dilaksanakan dalam siklus masing-masing siklus terdiri dari empat tahapan yaitu (1) Tahap Perencanaan (2) Tahap Tindakan (3) Observasi/evaluasi (4) Refleksi. Rancangan penelitian ini diperlihatkan seperti gambar di bawah ini.

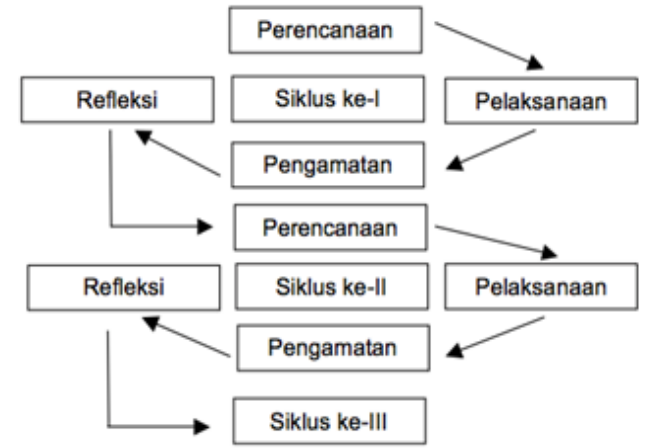

Gambar 1.Siklus Penelitian Tindakan, Sumber: Arikunto Suharsimi, dkk (2010)

Tahap Perencanaan tersebut adalah sebagai berikut: (1) Menentukan materi atau pokok bahasan yang akan dibahas (2) Membuat Rencana Pelaksanaan Pembelajaran (RPP) yang disesuaikan (3) Menyiapkan media pembelajaran dan Lembar Kerja Siswa (LKS) yang telah disesuaikan dengan materi yang akan diberikan (4) Membentuk kelompok siswa (heterogen) yang beranggotakan 4 orang (5) Menyiapkan instrumen penelitian untuk mengetahui pemahaman konsep yang telah dikuasai siswa.

Tahap pelaksanaan tindakan ini disesuaikan dengan rencana pelaksanaan pembelajaran (RPP) yang disesuaikan. Siklus I terdiri dari 3 (tiga) kali pertemuan yaitu 2 (dua) kali pembelajaran dan 1 (satu) kali tes akhir, sedangkan Siklus II terdiri dari 4 (Empat) kali pertemuan yaitu 3 (Tiga) kali pembelajaran dan 1 (satu) kali tes akhir. 
Observasi/Evaluasi, tahap evaluasi dilakukan untuk mengetahui hasil belajar IPA siswa. Kegiatan evaluasi dilakukan setiap proses pembelajaran berlangsung dengan pemberian tes evaluasi pada akhir siklus. Adapun hal yang di evaluasi adalah seluruh kegiatan dalam proses belajar mengajar. Pengamatan dan evaluasi terhadap tindakan yang diberikan pada pembelajaran dilakukan dengan mencatat kendala-kendala yang timbul selama berlangsungnya kegiatan

Refleksi ini dilakukan untuk merenungkan dan mengkaji hasil tindakan pada siklus I. Berdasarkan hasil evaluasi untuk mengetahui hasil belajar siswa pada siklus I maka selanjutnya dipikirkan solusi yang lebih efektif dan sesuai dengan karakteristik siswa untuk meningkatkan hasil belajar IPA siswa. Alternatif tindakan ini diterapkan menjadi tindakan baru pada rencana tindakan dalam penelitian tindakan kelas siklus II.

Dalam penelitian tindakan kelas digunakan analisis statistik deskriptif. Analisis statistik deskriptif adalah suatu cara pengolahan data yang dilakukan dengan jalan menerapkan rumus-rumus statistik deskriptif untuk menggambarkan suatu objek tertentu sehingga diperoleh kesimpulan umum (Agung, 2010).

Tujuannya adalah untuk menentukan tingkatan tinggi rendahnya hasil belajar IPA yang dikonversikan ke dalam (PAP) skala lima. Untuk mengetahui tingkat pencapaian hasil belajar IPA digunakan pedoman sebagai berikut.

Tabel 1 Pedoman Konversi PAP Skala 5

\begin{tabular}{cc}
\hline Persentase & Katagori \\
\hline $90-100$ & Sangat Tinggi \\
\hline $80-89$ & Tinggi \\
\hline $65-79$ & Cukup Tinggi \\
\hline $55-64$ & Rendah \\
\hline $0-54$ & Sangat Rendah \\
\hline & (Agung, 2010)
\end{tabular}

Untuk dapat menetapkan keberhasilan tindakan yang dilakukan, penetapan kriteria atau indikator keberhasilan mutlak diperlukan. kriteria atau indikator keberhasilan ditetapkan sebagai berikut: Hasil belajar IPA siswa dikatakan mengalami peningkatan jika rata-rata hasil belajar siswa pada siklus II lebih tinggi dari pada rata-rata hasil belajar siswa pada siklus I atau seterusnya sampai mencapai peningkatan yang diinginkan serta peningkatan ini disertai dengan terpenuhinya rata-rata nilai hasil belajar IPA siswa melalui model pembelajaran Kooperatif STAD $\geq 75$, daya serap dan ketuntasan belajar siswa yang tercapai $\geq 75 \%$.

\section{Hasil dan pembahasan}

Penelitian tindakan kelas ini dilaksanakan pada tanggal 11 Oktober 2016 sampai dengan tanggal 1 November 2016. Penelitian ini dilaksanakan dalam bentuk siklus, dengan subjek penelitian adalah siswa kelas IV Asemester ganjil SD No. 3 Dalung tahun pelajaran 2016/2017 yang berjumlah 28 orang yang terdiri dari 14 orang siswa perempuan dan 14 orang siswa laki-laki. Masing-masing siklus terdiri dari tiga kali pertemuan dan empat kali pertemuan, yaitu dua kali pertemuan siklus I untuk pembelajaran dan satu kali evaluasi dari tanggal 11 Oktober 2016 sampai 17 Oktober 2017 kemudian pada siklus II dilakukan tiga kali pertemuan untuk pembelajaran dan satu kali untuk evaluasi pembelajaran IPA melalui tes pada setiap akhir siklus dari tanggal 24 Oktober 2016 sampai 1 November 2016.

Siklus I Hasil belajar IPA secara individu pada siklus I belum mencapai indikator keberhasilan penelitian tindakan kelas, karena masih ada enam belas orang siswa yang memperoleh nilai $<75$ (dibawah KKM) atau 57,2 \% siswa yang belum mencapai KKM. Ketuntasan hasil belajar IPA siswa secara klasikal pada siklus I belum mencapai indikator keberhasilan penelitian tindakan kelas, karena baru mencapai 42,8 \% dan masih ada 57,2 \% siswa yang belum mencapai KKM.

Berdasarkan pelaksanaan tindakan pada siklus I yaitu setelah diterapkan model pembelajaran kooperatif STAD untuk meningatkan hasil belajar IPA, hasil penelitian menunjukan bahwa persentase nilai rata-rata hasil belajar pada pembelajaran IPA sebesar $62 \%$. Setelah dikonversikan ke dalam PAP skala 5 menunjukkan bahwa persentase hasil belajar IPA siswa pada siklus I berada pada kriteria Rendah. Ketuntasan belajar siswa pada siklus I baru mencapai 42,8 \%. Hal ini berarti masih terdapat 57,2 \% siswa yang memperoleh nilai di bawah KKM yang telah ditentukan oleh sekolah.

Dari hasil pengamatan dan temuan selama pemberian tindakan pada siklus I terdapat beberapa kendala yang dialami oleh siswa maupun guru. Kendala - kendala tersebut akan digunakan sebagai tindakan yang akan dilaksanakan pada siklus II. 
Kendala-kendala yang ditemukan pada tindakan siklus I sebagai berikut (1) Siswa belum bisa mengikuti pelajaran sesuai yang diharapkan, karena siswa baru pertama kali mengikuti proses pembelajaran menggunakan model pembelajaran kooperatif STAD. (2) Ada 6 orang siswa tidak mau bekerjasama pada saat kerja kelompok, hal ini disebabkan karena siswa yang lebih pintar dari anggota kelompoknya tidak mau bekerjasama dengan siswa yang memiliki kemampuan lebih rendah. (3) Ada 5 orang siswa dalam mengerjakan tugas yang belum bisa di mengerti mudah putus asa, karena pada saat diskusi siswa masih merasa takut dalam mengajukan pertanyaan, menjawab pertanyaan, maupun mengeluarkan pendapat pada kelompoknya masing-masing maupun guru. Sehingga siswa yang belum mengerti merasa putus asa dalam mengerjakan tugas. (4) Ada 5 orang siswa yang belum fokus dalam mengikuti pembelajaran. (5) Siswa yang memiliki kemampuan akademik lebih tinggi dalam kelompoknya masing-masing masih mendominasi dalam diskusi kelompoknya, sehingga beberapa siswa masih kurang menghargai gagasan atau pendapat temannya dan siswa yang mempunyai kemampuan akademik lebih rendah tidak dapat bagian dalam mengerjakan tugas-tugas kelompoknya masing-masing. (6) Dalam menyimpulkan materi pembelajaran tidak semua siswa ikut aktif memberikan pendapat tentang kesimpulan dari materi yang telah dibahas. Sebagian besar penyampaian kesimpulan pada akhir pembelajaran didominasi oleh siswa yang memiliki kemampuan akademik lebih tinggi.

Berdasarkan hambatan-hambatan tersebut maka dilakukan upaya untuk mengatasi permasalahan pada siklus I yaitu dengan menerapkan beberapa tindakan sebagai berikut (1) Sebelum pelaksanaan tindakan pada siklus II siswa ditekankan kembali mengenai langkah-langkah pembelajaran dengan menggunakan model pembelajaran kooperatif STAD. Kemudian guru juga menekankan kembali mengenai pelaksanaan pembelajaran, maupun aspek-aspek yang terkait dengan penilaian dan siswa dituntut untuk lebih aktif dan bertanggung jawab terhadap keberhasilan kelompoknya. (2) Memotivasi dan mengarahkan siswa agar mengikuti pembelajaran dengan baik. (3) Mengarahkan siswa untuk saling menghargai pendapat temannya pada saat kerja kelompok. (4) Menciptakan suasana belajar yang menyenangkan. (5) Memberikan penguatan dan penghargaan.

Beberapa tindakan yang telah diuraikan di atas diharapkan dapat meningkatkan kualitas dan proses pembelajaran sehingga dapat meningkatkan sikap ilmiah dan hasil belajar siswa pada siklus selanjutnya.

Siklus II. Pelaksanaan tindakan pada siklus II merupakan pengoptimalan dan antisipasi kendala yang muncul pada siklus I. Bertitik tolak dari hasil penelitian tindakan di atas, baik dari proses pembelajaran maupun hasil belajar yang dicapai siswa dalam pelajaran IPA, ternyata ada peningkatan hasil belajar IPA siswa. Hasil penelitian menunjukkan bahwa nilai hasil belajar klasikal pada siklus I : nilai rata-rata klasikal (M) sebesar 62. Pada siklus II nilai rata-rata klasikal (M) sebesar 88.

Dilihat dari kriteria keberhasilan yang telah ditentukan dalam penelitian ini, ketuntasan belajar siswa telah mencapai target yang ditentukan yakni 100\% dari jumlah siswa kelas IV A semester I SD No. 3 Dalung memperoleh nilai $\geq 75$ dan persentase nilai rata-rata hasil belajar IPA siswa secara klasikal sebesar $88 \%$ dengan katagori "Tinggi". Oleh karena itu tahap penelitian selanjutnya dihentikan hanya pada siklus II.

Untuk lebih jelasnya, peningkatan hasil belajar IPA siswa kelas IV A pada semester ganjil di SD No. 3 Dalung Tahun Pelajaran 2016/2017 pada siklus I dan siklus II dapat dilihat pada Tabel berikut.

Tabel 2. Rekapitulasi Data Hasil PTK Siklus I dan Siklus II

\begin{tabular}{ccccc}
\hline \multirow{2}{*}{ Aspek yang Diteliti } & TINDAKAN & $\begin{array}{c}\text { PAP } \\
(\%)\end{array}$ & PERSENTASE & KATEGORI \\
\hline \multirow{2}{*}{ Hasil Belajar IPA } & Siklus I & $55-64$ & $62 \%$ & Rendah \\
\cline { 2 - 5 } & Siklus II & $80-89$ & $88 \%$ & Tinggi \\
\hline
\end{tabular}

Hasil analisis terhadap hasil belajar IPA siswa dengan model STAD pada siklus I dan II ditampilkan dalam diagram.

Secara lengkap peningkatan hasil belajar IPA siswa pada siklus I dan siklus II di atas dapat disajikan seperti pada Gambar berikut. 


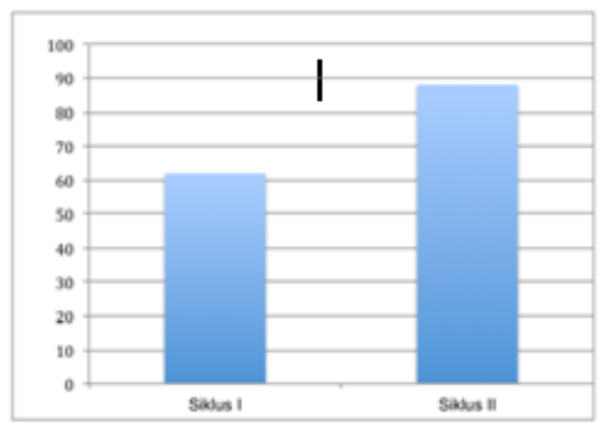

Gambar 02 Diagram Batang Peningkatan Hasil Belajar IPA siswa Kelas IVA SD No. 3 Dalung

Setelah dilakukan analisis penelitian, terdapat temuan-temuan selama pelaksanaan tindakan siklus II yaitu sebagai berikut. (1) Secara umum proses pembelajaran telah berjalan sesuai dengan Rencana Pelaksanaan Pembelajaran (RPP) yang dibuat. (2) Siswa sudah terbiasa dalam melaksanakan diskusi kelompok dan aktif berdiskusi bersama teman kelompoknya, baik itu bertanya, menjawab pertanyaan, mengemukakan pendapat kepada kelompoknya masing-masing maupun kepada guru. sehingga siswa terlihat antusias dalam berdiskusi bersama anggota kelompoknya masingmasing. (3) Siswa yang memiliki kemampuan akademik lebih tinggi dalam kelompoknya sudah bisa menghargai pendapat temannya dan membantu temannya yang lain dalam memecahkan masalah. (4) Terdapat 28 orang siswa yang mengerjakan soal lebih teliti dengan cara menguraikan proses dalam mendapatkan hasil walaupun sebagian besar sudah memperoleh hasil yang benar. (5) Semua siswa sudah ikut aktif menyimpulkan materi pembelajaran yang telah dibahas. (6) Semua kelompok pada saat melakukan diskusi sudah melakukan kerjasama dengan baik bersama anggota kelompoknya.

Penerapan model pembelajaran kooperatif STAD untuk meningatkan hasil belajar pada penelitian yang dilakukan ternyata relatif dapat meningatkan hasil belajar IPA siswa kelas IV A semester I SD No. 3 Dalung. Ini terbukti berdasarkan dari analisis pelaksanaan tindakan siklus I dan pelaksanaan siklus II diperoleh nilai rata-rata hasil belajar siswa pada siklus I yaitu sebesar 62 yang berada di kategori rendah dan nilai rata-rata hasil belajar IPA pada siklus II yaitu sebesar 88 yang berada di kategori tinggi. Hal ini menunjukkan bahwa masalah / kendala yang terjadi pada siklus I relatif sudah dapat teratasi dengan baik.

Model pembelajaran kooperatif STAD merupakan strategi alternatif untuk mencapai tujuan pembelajaran IPA antara lain meningatkan kemampuan siswa untuk bekerjasama dengan siswa lain, dan pada saat yang bersamaan dapat meningatkan prestasi akademik siswa. Selain itu pembelajaran kooperatif tipe STAD untuk meningatkan hasil belajar IPA sangat sesuai dengan pedidikan IPA karena dapat membantu siswa untuk mampu berpendapat sendiri (Rusman, 2013).

Siswa belajar dan beraktivitas sendiri untuk memperoleh pengalaman, pengetahuan, pemahaman dan tingah laku lainnya serta mengembangkan ketrampilanya yang bermakna. Sehingga dalam hal ini, kegiatan atau akttivitas belajar siswa merupakan pondasi dan prinsip fundamental untuk mencapai keaktifan dan hasil belajar yang lebih baik. Hasil belajar menujuk pada perubahan struktur pengetahuan individu sebagai hasil dari situasi belajar. Hasil belajar beranekaragaman besarnya, baik yang menyangkut belajar fakta sederhana maupun ketrampilan-ketrampilan teknis yang bersifat kompleks.

Hasil penelitian ini mebuktikan bahwa melalui pembelajaran kooperatif STAD ada peningkatan dalam beberapa hal yaitu (1) keaktifan siswa meningkat dalam kegiatan kelompok, mengerjakan tugastugas dan berpikir bersama, (2) hasil belajar siswa meningkat pada ranah kognitif, afektif, dan psikomotor, (3) respon terhadap proses pembelajaran juga meningkat. Dari seluruh kegiatan yang diberikan kepada siswa dapat disimpulkan bahwa pembelajaran yang dilaksanakan merupakan hal baru, siswa merasa senang mengikuti pelajaran, tugas lebih mudah dikerjakan, termotivasi mengerjakan tugas, merasa siap untuk menjawab pertanyaan, dapat memusatkan perhatian, serta lebih bergairah. Hal ini menujukan bahwa pembelajaran kooperatif STAD untuk meningatkan hasil belajar IPA mendapat respon positif dari siswa, dengan pembelajaran kooperatif STAD untuk meningatkan hasil belajar siswa menjadi lebih mudah belajar disebabkan adanya bimbingan dari teman sekelompoknya melalui diskusi yang berlangsung.

\section{Simpulan dan Saran}

Dengan adanya penerapan model pembelajaran kooperatif STAD terjadi peningatkan hasil belajar IPA siswa kelas IV A Tahun Pelajaran 2016/2017 di SD No. 3 Dalung. Hal ini berdasarkan rata-rata hasil belajar IPA siswa pada siklus I sebesar 62 \% dengan katagori "Rendah" mengalami peningkatan 
sebesar $26 \%$ pada siklus II, sehingga rata-rata hasil belajar IPA siswa menjadi $88 \%$. Dalam pedoman PAP Skala 5 rata-rata hasil belajar IPA siswa kelas IV A termasuk dalam katagori "tinggi".

Adapun saran yang dapat disampaikan yaitu : (1) Siswa disarankan lebih sering menggunakan model pembelajaran kooperatif STAD sebagai salah satu alternatif untuk meningkatkan motivasi dalam belajar dan juga siswa disarankan lebih berpartisipasi aktif dalam mengikuti pembelajaran sehingga pembelajaran akan lebih bermakna. (2) Guru kelas, diharapkan dapat memanfaatkan model pembelajaran kooperatif STAD sebagai salah satu alternatif pembelajaran dalam upaya meningkatkan hasil belajar IPA siswa, serta dapat dijadikan acuan bagi guru dalam memilih dan mengembangkan model maupun metode belajar yang inovatif dan dinamis sesuai dengan materi yang diajarkan. (3) Sekolah disarankan dapat menjadi informasi berharga bagi kepala sekolah untuk mengambil suatu kebijakan yang paling tepat dalam upaya pemanfaatan strategi pembelajaran yang efektif dan efisien.

\section{Daftar Pustaka}

Angga Wiguna, Sang Gede., I Wayan Widiana, Dewa Nyoman Sudana. Penerapan Pembelajaran Berbasis Otak Untuk Meningkatkan Kemampuan Pemecahan Masalah Matematika Siswa Kelas V Sekolah Dasar. Mimbar PGSD Vol 5 No 2 Tahun 2016. (http://ejournal.undiksha.ac.id/index.php/JJPGSD/ article/view/7776).

Agung, A.A Gede. 2010. Metedologi Penelitian Pendidikan. Singaraja: Aditya Media Publishing.

Agusditya, Putu Handy., I.G.A.A. Sri Asri, I Made Suara. The Effect of Scientific Approach Based on Portfolio Assessment towards the Learning Outcomes of Civic Education of the Students Grade V Viewed from the Tendency of Observing Objects on Theme 7 SDN 4 Ubung. Journal of Evaluation and Research in Education (JERE) Vol 1 No 1 Tahun 2017. (http://ejournal.undiksha.ac.id/ index.php/JERE/article/view/9842).

Agus Suarimbawa, Kadek., A. A. I. N. Marhaeni, GAP Suprianti. 2017. An Analysis of Authentic Assessment Implementation Based on Curriculum 2013 in SMP Negeri 4 Singaraja. Journal of Evaluation and Research in Education (JERE) Vol 1 No 1 Tahun 2017 (http://ejournal.undiksha.ac.id/ index.php/JERE/article/view/9551).

Arikunto, S DKK. 2010. Penelitian Tindakan Kelas. Jakarta : PT. Bumi Aksara.

Aunurrahman. 2012. Belajar dan Pembelajaran. Bandung : Alfabeta.

Ayu Suryaningsih, Ni Made., I Made Elia Cahaya, Christiani Endah Poerwati. 2016. Implementasi Pembelajaran Inkuiri Terbimbing Berbasis Permainan Dalam Meningkatkan Kreativitas Anak Usia Dini. Jurnal Pendidikan Indonesia Vol 5. No 2 tahun 2016. (http://ejournal.undiksha.ac.id/ index.php/JPI/article/view/8559).

Dantes, Nyoman. 2012. Metode Penelitian. Yogyakarta : PT. Andi Yogyakarta.

Hadi, L. S., Agustriyana, Subagiyo Subagiyo. 2017. Project Based Learning on Casting of Aluminium Tensile Test Specimen for Mechanical Engineering Students, State Polytechnic of Malang on Odd Semester of Academic Year 2016/2017. Journal of Evaluation and Research in Education (JERE) Vol 1 No 1 Tahun 2017. (http://ejournal.undiksha.ac.id/ index.php/JERE/article/view/9844).

Januarti, Ni Ketut., I Ketut Dibia, I Wayan Widiana. 2016. Analisis Kesulitan Belajar Dalam Pembelajaran Membaca Cepat Siswa Kelas V Sd Gugus Vi Kecamatan Abang. Mimbar PGSD Vol 4 No 1 Tahun 2016. (http://ejournal.undiksha.ac.id/index.php/JJPGSD/article/view/7442).

Jasdilla. 2016. Hasil Belajar Dan Pembelajaran Kooperatif Tipe Think Pair Share (Tps). Journal Pendidikan Indonesia P-ISSN: 2303-288X E-ISSN: 2541-7207 Vol. 6, No.1, April 2016. http://ejournal.undiksha.ac.id/index.php/JPI/article/view/9253/6328

Hamalik, Oemar. 2014. Kurikulum dan Pembelajaran. Jakarta : PT. Bumi Aksara.

Iskandar. 2009. Penelitian Tindakan Kelas. Jakarta : PT. Gaung Persada Press.

Jihat, Asep DKK. 2008. Evaluasi Pembelajaran. Yogyakarta : PT. Multi Press.

Komalasari, Kokom. 2010. Pembelajaran Kontekstual, Konsep dan Aplikasi. Bandung : PT. Refika Aditama. 
Laba Laksana, Dek Ngurah. 2016. Miskonsepsi Dalam Materi IPA Sekolah Dasar. Jurnal Pendidikan Indonesia Vol 6.No 2 tahun 2016. (http://ejournal.undiksha.ac.id/ index.php/JPI/article/view/8588).

Lasmawan Wayan. 2010. Menelisik Pendidikan IPS Dalam Perspektif Kontekstual dan Empiris. Singaraja : Mediakom Indonesia Press Bali.

Oka Sugiarta, Gst Pt., I Wayan Widiana, I Dewa Kade Tastra. Penerapan Model Pembelajaran Akselerasi (Accelerated Learning) Untuk Meningkatkan Hasil Belajar Ipa Siswa Kelas V di SD N 8 Banyuning. Mimbar PGSD Vol 6 No 3 Tahun 2016. (http://ejournal.undiksha.ac.id/index.php/JJPGSD/ article/view/8600).

Muslich, Masnur. 2011. Penilaian Berbasis Kelas dan Kompetensi. Bandung : PT. Refika Aditama.

Nurkancana, Wayan dan Sunartana. 1990. Evaluasi Hasil Belajar. Surabaya: Usaha Nasional.

Rusman. 2013. Model-model Pembelajaran, Mengembangkan Profesionalisme Guru. Jakarta : PT. Raja Grafindo Persada.

Septiani Ari Pertiwi, Ni Luh., Ni Wayan Arini, I Wayan Widiana. 2016. analisis Tes Formatif Bahasa Indonesia Kelas IV Ditinjau Dari Taksonomi Bloom Revisi di Gugus XIII Kecamatan Buleleng Tahun Ajaran 2015/2016. Mimbar PGSD Vol 5 No 2 Tahun 2016. (http://ejournal.undiksha.ac.id/index.php/JJPGSD/ article/view/7692).

Setyosari, Punaji. 2013. Metode penelitian Pendidikan \& Pengembangan. Jakarta : PT. Kharisma Putra Utama.

Slavin. Robert E. 2016. Cooperative Learning, Teori, Riset dan Praktik. Bandung : PT. Nusa Media.

Surata I Wayan. 2014. Pengaruh Model Pembelajaran Kooperatif Tipe STAD Terhadap Hasil Belajar IPA Pada Siswa Kelas V Semester Genap Tahun Pelajaran 2012/2013 Di SD Gugus IV Kecamatan Buleleng Kabupaten Buleleng: Universitas Pendidikan Ganesha.

Susanto, Ahmad. 2013. Teori Belajar Pembelajaran di Sekolah Dasar. Jakarta : PT. Kencana Prenada Media Grup.

Trianto. 2007. Model-model Pembelajaran Inovatif Berorientasi Konstruktivistik, Konsep, Landasan Teoritis, Praktis dan implementasinya. Jakarta : PT. Prestasi Pusaka Publisher.

Trianto. 2015. Model-model Pembelajaran Terpadu, Konsep, Strategi, dan Implementasinya dalam Kurikulum Tingkat Satuan Pendidikan (KTSP). Jakarta : PT. Bumi Aksara.

Widiana, dkk. 2014. Pengaruh Model Pembelajaran Kooperatif Tipe Think Pair Square (Tps) Berbantuan Kartu Kerja Terhadap Hasil Belajar Matematika. Jurnal Mimbar PGSD Universitas Pendidikan Ganesha Jurusan PGSD (Vol: 2 No: 1 Tahun 2014).

Widiana, I Wayan. 2016. Pengembangan Asesmen Proyek Dalam Pembelajaran IPA di Sekolah Dasar. Jurnal Pendidikan Indonesia Vol 6.No 2 tahun 2016. (http://ejournal.undiksha.ac.id/ index.php/JPI/article/view/8154). 